\title{
Development of a site-conditions map for the Campania-Lucania region (southern Apennines, Italy)
}

\author{
Luciana Cantore $^{1,{ }^{\star}}$, Vincenzo Convertito ${ }^{2}$, Aldo Zollo ${ }^{1}$ \\ ${ }^{1}$ Università degli Studi di Napoli «Federico II», Dipartimento di Scienze Fisiche, Napoli, Italy \\ ${ }^{2}$ Istituto Nazionale di Geofisica e Vulcanologia, Osservatorio Vesuviano, Napoli, Italy
}

\author{
Article history \\ Received March 8, 2010; accepted July 27, 2010. \\ Subject classification: \\ Site-conditions map, Site effects, Seismic hazard, Shear-wave velocity, Site dominant period.
}

\section{ABSTRACT}

Having a reliable site-conditions estimate is an important step to analyze and predict earthquake ground motions. To provide this information for the Campania-Lucania region (southern Apennines, Italy), and in the framework of a collaboration with the regional branch of the Dipartimento della Protezione Civile (Italian National Civil Protection Agency), the geological units shown on a 1:250,000 scale geological map have been combined together into four categories based on age and geological similarities. According to the site classification defined in engineering building codes, each site has been assigned a class, a value or range of values of the average shear-wave velocity to $30 \mathrm{~m}$ (Vs30), and the site-dominant period. Thus, we have digitized the category boundaries from the map, tracing only the geological contacts that separate the units of different site classes. The accuracy of the site-conditions map is only limited by the number of Vs profiles used to compute the Vs30, and geologic data available to date. Analyses with new data will allow updates and modifications to this map. The resulting site classification map provides a helpful tool to better characterize the site effects for those applications where amplification values at large scale are need, such as ground-shaking maps or seismic hazard maps.

\section{Introduction}

Local geological conditions can amplify or suppress seismic ground motion, modifying shaking intensity in both the time and frequency domains [Bard and Bouchon 1985, Bard et al. 1988]. Studies of historic and recent earthquakes have indicated that damage at an unconsolidated site can be 10 -fold worse than at a rock site, even when their distances from the ruptured fault are the same. During both the 1906 San Francisco earthquake (M 7.8) and the 1989 Loma Prieta earthquake (Ms 7.1), for example, the local amplification over soft soils was responsible for intensity variations as large as two degrees. Nearly all of the recent destructive events, such as Michoacan, Messico 1985, Spitak, Armenia 1988, Iran 1990, Philippines 1990, Northridge 1994, Kobe 1995, and others, have provided dramatic evidence of site effects. As a consequence, seismologists and engineers have conducted many studies to quantify how seismic energy is modified by the physical properties of the near-surface materials, and how engineering structures will behave during strong ground shaking.

Within this framework, a uniform estimation of site conditions is a necessary component in the prediction of nearsource ground motion. Recently, the measured shear-wave velocity (Vs) in shallow subsurface materials has become the most commonly used parameter to define site classifications and to correct the predictions of spectral amplitude values. This Vs parameter is an effective measure of the quality of foundation soils, because it depends on basic physical properties, such as density, porosity and degree of cementation of the materials through which the seismic waves propagate. For this purpose, many drilling programs have been conducted in several areas to establish important correlations between seismic response and average shearwave velocities of various geological units [Joyner and Fumal 1985, Boore et al. 1993, Borcherdt 1994]. Joyner et al. [1981] proposed that velocity to a depth corresponding to onequarter wavelength of the period of interest could represent the local site conditions. The need to have detailed subsurface information, and the complexity of using this approach, make the quarter-wavelength method difficult to apply.

Recent studies have recommended alternative techniques that simplify the use of Vs in ground-motion predictions. Borcherdt et al. [1991] suggested that site conditions can be classified on the basis of the average shearwave velocity to a depth of $30 \mathrm{~m}$ (Vs30), in agreement with the typical depth that can be reached with drill rigs in a single day. This allows sites to be classified unambiguously by using only one parameter. Recent code provisions for buildings and other structures (1997 and 2003 NEHRP-UBC Site Classifications, Eurocode 8, or EC8, 2003, and others) have 


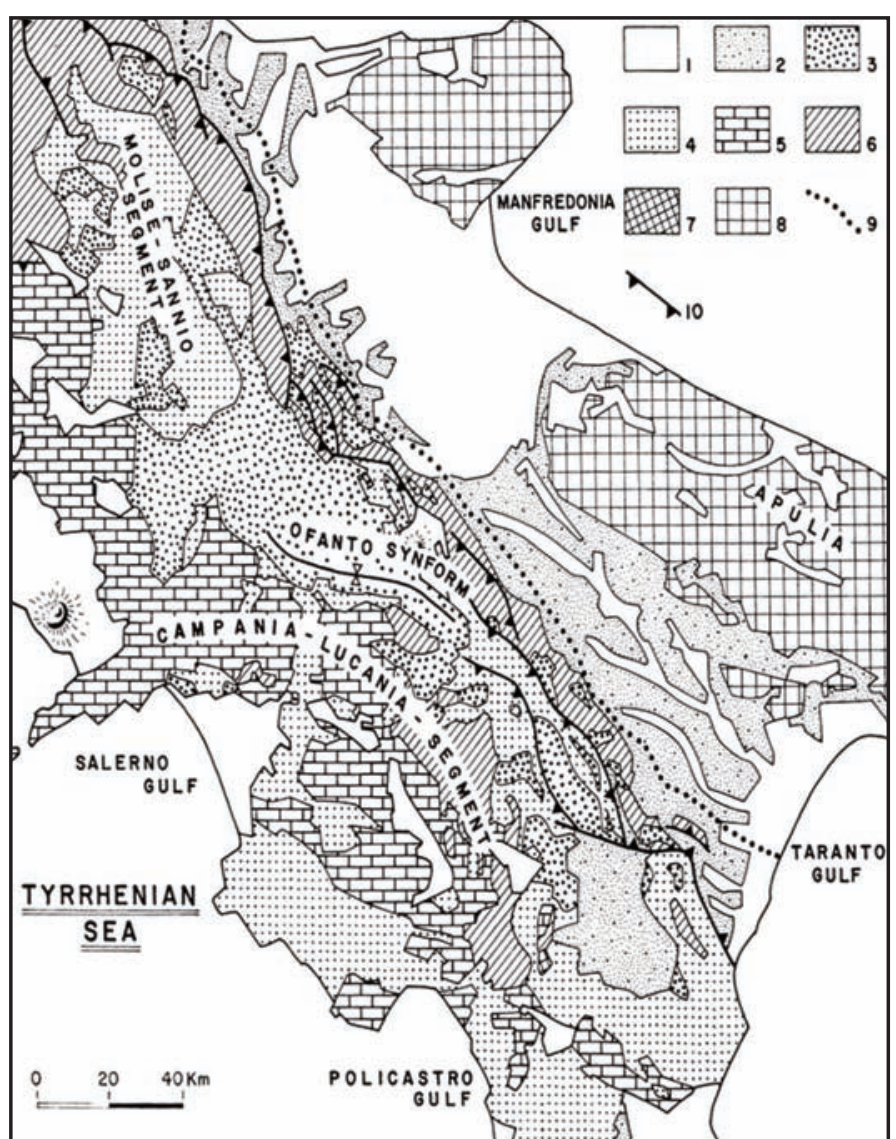

Figure 1. Simplified geological map of the central and southern Apennines [from Cinque et al. 1993]. 1) Continental and paralic Middle Pleistocene to Holocene deposits; Quaternary volcanoes. 2) Upper Pliocene-Lower Pleistocene marine to continental deposits, including the Bradano cycle. 3) Upper Tortonian to Upper Pliocene clastic deposits accumulated in piggy-back basins formed on top of the advancing nappes. 4) Appenninic nappes derived from internal paleogeographic domains, originally located between the European plate margins and the western carbonate-platform system. 5) Appenninic nappes derived from the western carbonateplatform-system-related marginal areas. 6) Appenninic nappes derived from a basinal realm originally located between the western platform and eastern platform domains. 7) Mt. Alpi unit. 8) Mesozoic-Tertiary carbonates of the Apulia foreland. 9) Frontal ramp of the Apennine thrust sheets. 10) Out-of-sequence thrust.

defined site classifications based on Vs30.

Recognition of the importance of ground-motion amplification from the regolith has led to the development of a standardized approach for mapping seismic site conditions through measuring or mapping Vs30 [Park and Elrick 1998, Wills et al. 2000, Holzer et al. 2005]. This has included quantifying both amplitude- and frequency-dependent site amplification correction factors [Borcherdt 1994] for future earthquake scenario studies. Boore et al. [1993, 1994, 1997] introduced site factors based on Vs30 in their empirical attenuation relationships, to take into account the potential modifications of ground shaking by local site conditions. These site factors can be used to correct large-scale groundshaking maps, such as those provided in near real time or for seismic hazard.

A key aspect of the calculation of ground-shaking maps is represented by the estimation of Ground-Motion
Predictive Equations (GMPEs). These GMPEs are empirical equations that can provide strong ground-motion parameters given the earthquake magnitude and the sourceto-site distance [Abrahamson and Silva 1997, Akkar and Bommer 2007, Boore and Atkinson 2008]. Several studies have now highlighted the importance of retrieving and/or refining GMPEs also for low-magnitude seismic events [Frisenda et al. 2005, Massa et al. 2007] for which attenuation effects that are related to the tectonic area of interest can be predominant with respect to source effects. In practice, these codes use corrective coefficients for peak parameters, based on geological maps obtained by grouping the main geological formations that outcrop in the area of interest [Wald et al. 1999, Convertito et al. 2010, Emolo et al. 2011].

At present, maps of seismic site conditions on regional scales are not always available because they require substantial investment in geological and geotechnical data acquisition, as well as interpretation. Such maps are only available for a few regions, which are generally in seismically active urban areas of the World.

Park and Elrick [1998] classified the geologic materials in southern California using the age units reported on geological maps. They characterized three main general categories that roughly correlated with the common site-condition terms: Quaternary sediments $(\mathrm{Q})$, Tertiary sediments and soft rock $(\mathrm{T})$, and Mesozoic hard rock $(\mathrm{M})$.

For the Italian territory, the Istituto Nazionale di Geofisica e Vulcanologia (INGV) has introduced a role for local geology in seismic hazard evaluation at a national scale [Cultrera et al. 2003, Luzi and Meroni 2007]. This has been achieved by grouping the geological formations of the 1:500,000 Italian geological map into three classes: A, B, C according to the EC8 provisions.

This article discusses our effort to build a siteclassification map for the Campania-Lucania region (southern Apennines, Italy). This study is part of a collaboration with the regional branch of the Dipartimento della Protezione Civile (Italian National Civil Protection Agency), which requires that maps of peak ground acceleration (PGA), peak ground velocity (PGV), and instrumental intensity should be provided in any immediate post-event period occurring in Campania-Lucania, southern Italy [Convertito et al. 2010]. The Campania-Lucania region is one of the higher seismichazard regions in Italy [Cinti et al. 2004]. It has experienced numerous strong earthquakes from medium to large magnitudes, with the most recent event represented by the 1980 Irpinia earthquake (Ms 6.9) that resulted in about 3,000 deaths and enormous damage (Figure 2). The high density of inhabitants, the quality of the buildings, and the dissemination of industrial facilities, give the CampaniaLucania region a rather high seismic risk exposure.

To achieve this, the geologic formations from a 1:250,000 scale regional geological map, have been sorted 
into four macro-classes, described by units that have similar ages and physical properties (grain size, hardness and fracturing). These macro-classes have been considered representative of Quaternary alluvium (Q), QuaternaryTertiary volcanic rock (V), Tertiary sediments and soft rock (T) and Mesozoic hard rock (M). To design the CampaniaLucania site-conditions map, these categories have been digitized on the 1:250,000 scale regional geological map, tracing only the geologic contacts that separate the units belonging to the different categories. According to the EC8 soil classes, we have assembled a database of Vs profiles from the National Strong Motion Network (known as RAN: Rete Accelerometrica Nazionale) [Working Group ITACA 2010], and used computed Vs30 to characterize these QVTM units. Due to the wide extension of the map and to the lack of Vs profiles in most geological units, we have classified the geological units on the basis of the Vs measurements where available, and on lithological and age criteria for those units without Vs profiles.

The site-conditions map built with our current level of information provides an outline of surface geology characteristics that can be used to account for site effects in the ground-shaking maps. We stress that the accuracy of this map will evolve as more shear-wave velocity measurements and more geological information become available, in order to highlight significant variations in site responses for different geologic unit.

\section{Geological and seismological settings of the Campania- Lucania, southern Apennine region.}

The southern Apennine mountain chain (Italy) is a Neogene, post-collisional, east-verging thrust belt that formed as the result of the west-dipping subduction of the Apulian-Ionian lithosphere [Doglioni et al. 1996]. The belt is associated with the Tyrrhenian back-arc basin to the West, and with the Bradano foredeep to the East. During the middle Miocene-upper Pliocene, several compressive tectonic phases were associated with the collision between the African and European margins, resulting in thrusting and piling of different units towards stable domains of the Apulo-Adriatic foreland (Figure 1). From late Tortonian to Quaternary, all of the system rapidly migrated eastwards as a consequence of the retreating of the sinking foreland lithosphere [Patacca and Scandone 1989, Patacca et al. 1990, Pescatore et al. 1999].

The structural complexity of the Campania-Lucania region, is due to different paleogeographical domains that are involved in the building of the southern Apennine thrust belt. The basinal facies terrains have been involved in ductile deformations, while the carbonate platform sequences, in brittle deformations. Additionally, the deformation did not proceed cylindrically, but it was characterized by out-ofsequence thrust-propagation processes [Roure et al. 1991].

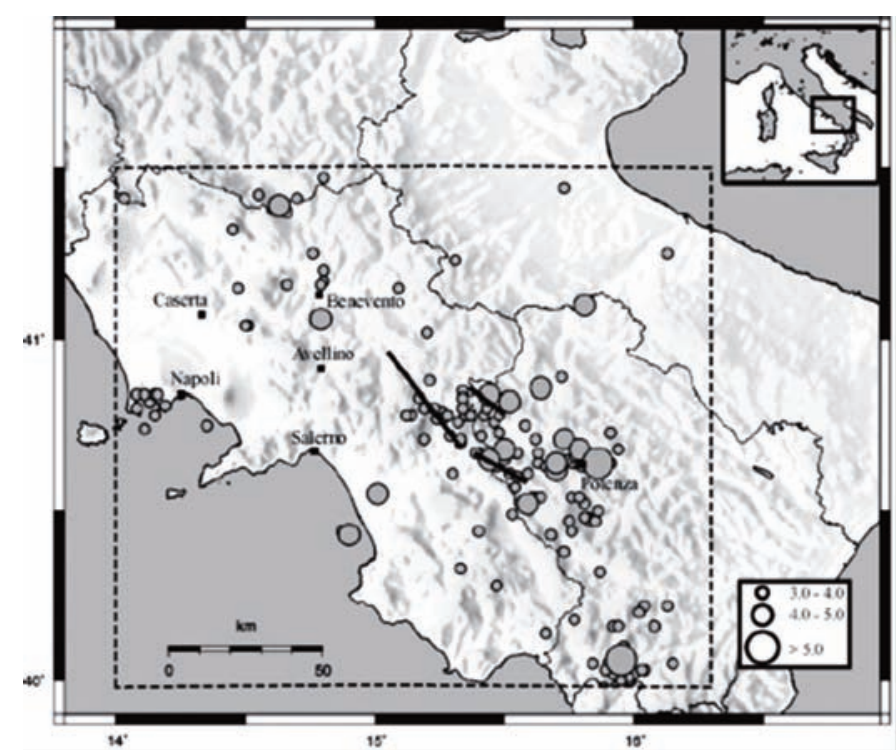

a)

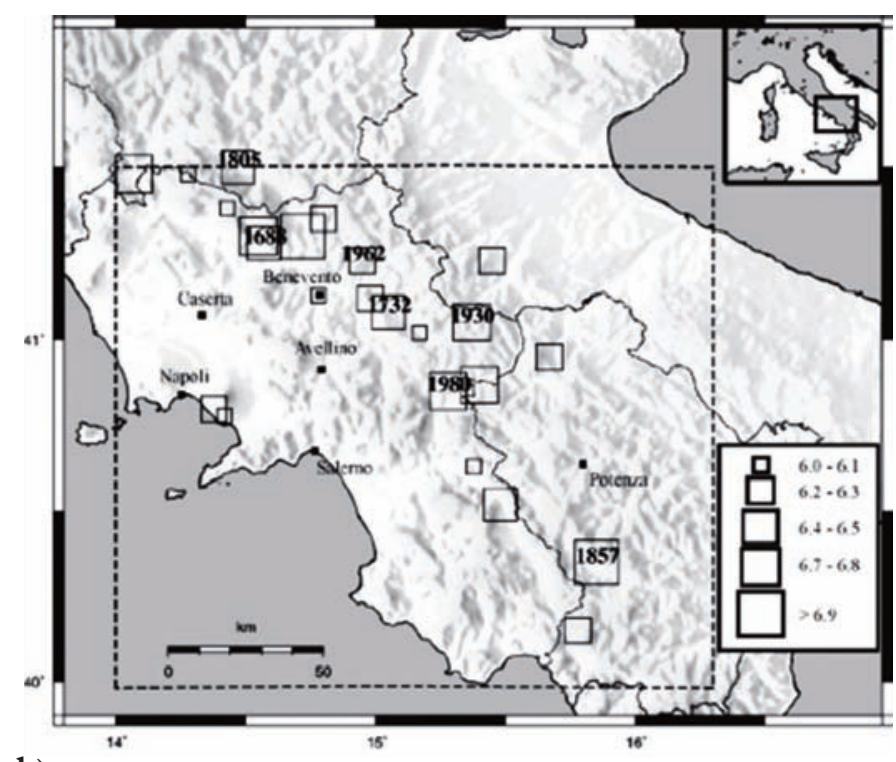

b)

Figure 2. a) Map of the recent instrumental seismicity with $M>2.5$ recorded by the INGV in the period 1981-2002 in the region defined by the dashed rectangle [CPTI Working Group 1999]. Dimensions of the circles are proportional to magnitude. Black lines, surface projection of the three fault segments that broke in the 23 November 1980 earthquake (M 6.9). b). Locations of the main historical earthquakes retrieved from the CFTI database (Catalogo dei Forti Terremoti in Italia) [Boschi et al. 1997] within the region defined by the dashed rectangle. The box dimensions are proportional to magnitude. The best-constrained historical earthquakes are reported along with their date of occurrence [from Weber et al. 2007].

During the upper Pliocene-lower Pleistocene, the tectonic evolution resulted in the mountain chain subdivision into the NNW-SSE-trending Molise-Sannio region, and the WNWESE-trending Campania-Lucania region. Afterwards, in the Middle Pleistocene, the southern Apennine wedge was uplifted and was involved in a NE-SW extensional tectonic event. This stress regime resulted in the development of large extensional and transtensional structures, and it is still active and responsible for the present-day seismicity of the region [Anderson and Jackson 1987]. Most of the 


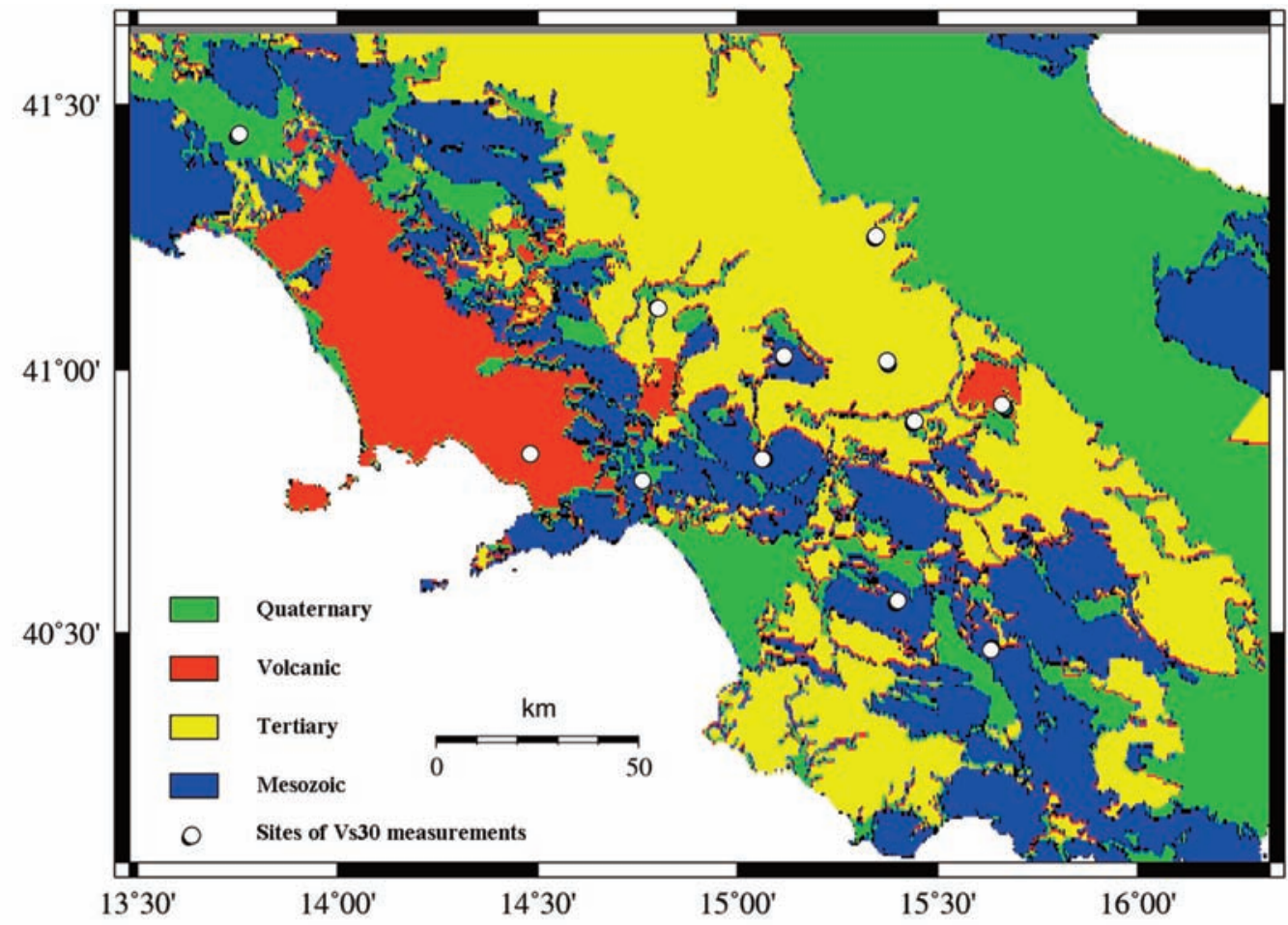

Figure 3. The QVTM site-conditions map, 1:250,000 scale [Cantore 2008]. White circles, sites of Vs30 measurements.

earthquakes are located in the narrow upper-crustal seismic belt (30-50 km). In particular, two different clusters of crustal earthquakes can be identified: the westernmost, with shallow earthquakes (depths $<20 \mathrm{~km}$ ) centered on the axis chain (Irpinia area); and the easternmost, with deeper earthquakes (about $20-40 \mathrm{~km}$ ) located on the outer margin of the chain (Potentino area) and in the foredeep. These earthquakes have different focal solutions, indicating a pure extensional regime to the West (Irpinia area), and a strike-slip regime to the East (Potentino area). Moreover, it is possible to define a third zone that is characterized by low seismicity and located within the Apennine chain, from Vallo di Diana to the Agri Valley (Figure 2a).

The larger seismic events that have occurred along the Apennine chain have shown normal faulting mechanisms, in agreement with the regional NE-trending extension. In this context, the Campania-Lucania region is one of the most active seismic zones of the southern Apennines, where important extensional faults are in connection with the major seismic events that have struck the area historically [Westaway 1992]. The location and magnitude of the historic earthquakes retrieved from the CFTI (Catalogo dei Forti Terremoti in Italia) [Boschi et al. 1997] are shown in Figure 2b. Among these, there is the most recent event: the 1980 Irpinia earthquake (Mw 6.9) [Westaway and Jackson 1987, Bernard and Zollo 1989]. More recent studies have indicated that the 1980s faulted area currently involves intense seismic activity, with the occurrence of small to moderate-sized events. For this area, Cinti et al. [2004] assigned a relatively high probability (about 30\%) for a moderate to large earthquake to occur within the next 10 years.

\section{Developing of a site-conditions map from a geological map}

The first step for the generation of a site-conditions map to be used as a Vs category map consists of selecting an appropriate geological map. Geological maps show units that are distinguished by their ages, lithologies, grain size, and other factors that might be correlated with Vs. Usually, the most detailed geological maps are at 1:50,000 scale, where units that have major influences on the amplification of ground motion, the Quaternary units, are split into different subunits. For the time being, only maps at 1:100,000 scale are complete and available for the study region. To cover the whole area, we would have had to assemble several 1:100,000 geological scale maps into a uniform digital map. Another alternative was to use a 1:250,000 scale geological map that completely includes the region. Although more detailed geological maps can provide better site-conditions maps, in the present study, we chose to use a larger, albeit less detailed, map to completely cover the region of interest with a single map that was readily available, rather than to work with an unmanageable number of maps. Thus, we used the 1:250,000 scale geological map of southern Italy of Bonardi et al. [1992].

The southern Apennine area is characterized by widespread Quaternary cover, a few outcrops of Pliocene clastic deposits, and various Tertiary sedimentary successions. These main units can be grouped in three belts ranging from East to West, and are identified as follows:

1. Successions with basinal to marginal facies, ranging in age from Cretaceous to Miocene, tectonically lying on PlioPleistocene foredeep deposits.

2. Successions with shallow-water, basinal and shelfmargin facies, ranging in age from middle Triassic to Miocene 
MESOZOIC

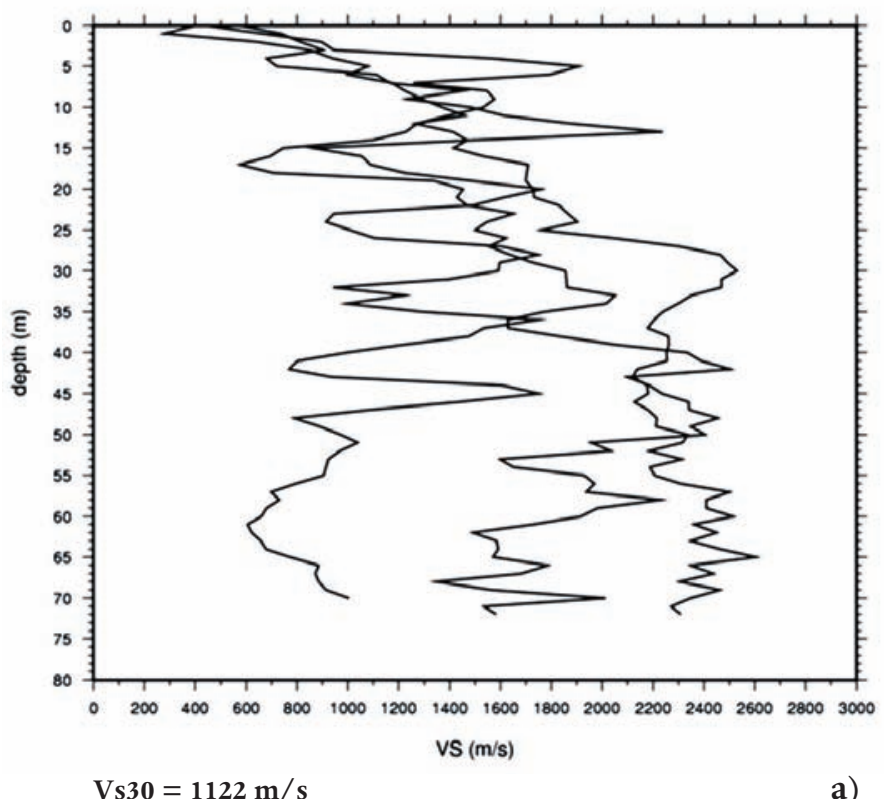

TERTIARY

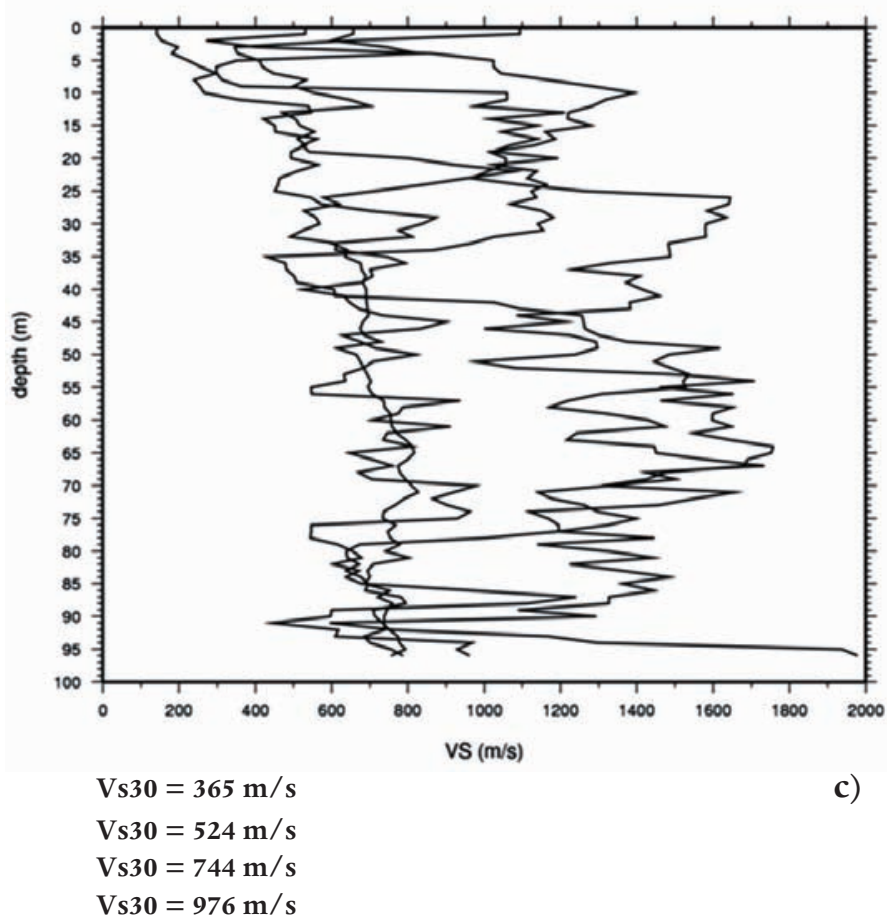

QUATERNARY

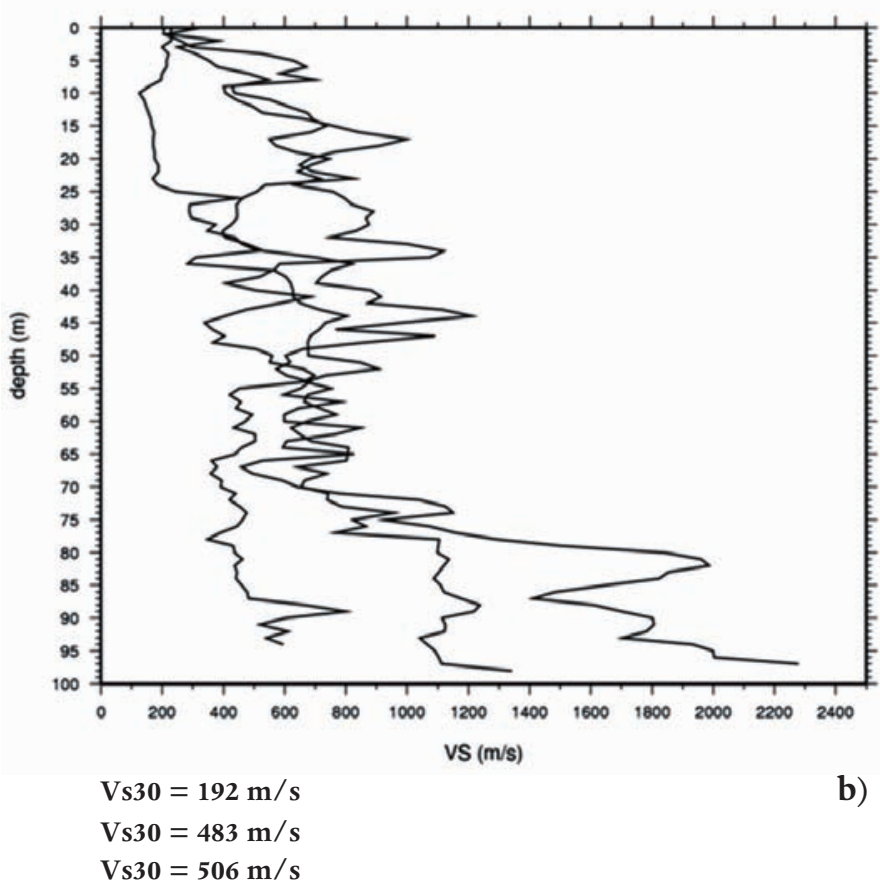

VOLCANIC

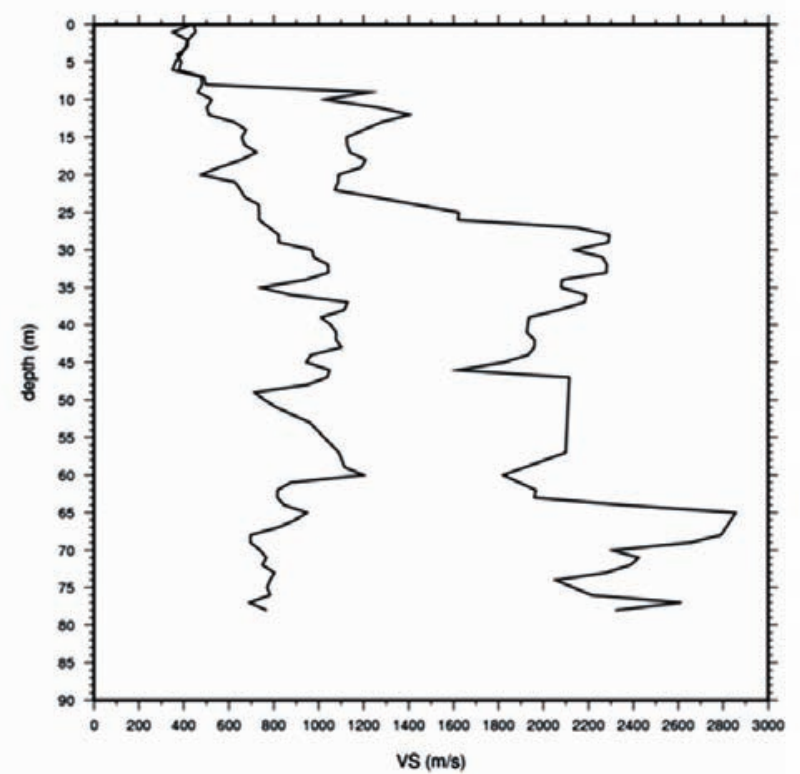

Vs30 $=539 \mathrm{~m} / \mathrm{s}$

Vs30 $=697 \mathrm{~m} / \mathrm{s}$

Figure 4. Shear-wave velocity profiles and the calculated Vs30 for the Mesozoic (a), Quaternary (b), Tertiary (c) and Volcanic (d) categories.

(«Lagonegro units»), overthrust on the previous units.

3. Triassic to Miocene carbonate platform successions («Appeninic platform units»), overthrust on the Lagonegro units.

Moreover, volcanic rocks are extensively diffuse in the Campania-Lucania region. The main volcanic vents are: the Campi Flegrei, an active volcanic complex located on the eastern border of the region, Mt. Somma-Vesuvio, an active volcano situated in the central area near Naples, and Mt. Vulture, an inactive volcano located on the western border of the region.

All of the units have been sorted into four different categories on the basis of lithological and age criteria, as proposed by Park and Elrick [1998]. The resulting four classes, which are expected to have similar Vs, are: Quaternary alluvial deposits (Q), Quaternary-Tertiary volcanic rock (V), Tertiary sediments and soft rock (T), and Mesozoic hard rock $(\mathrm{M})$. The four categories (QVTM) have been overlapped on the 1:250,000 scale regional map, tracing only the geological contacts that 
a)

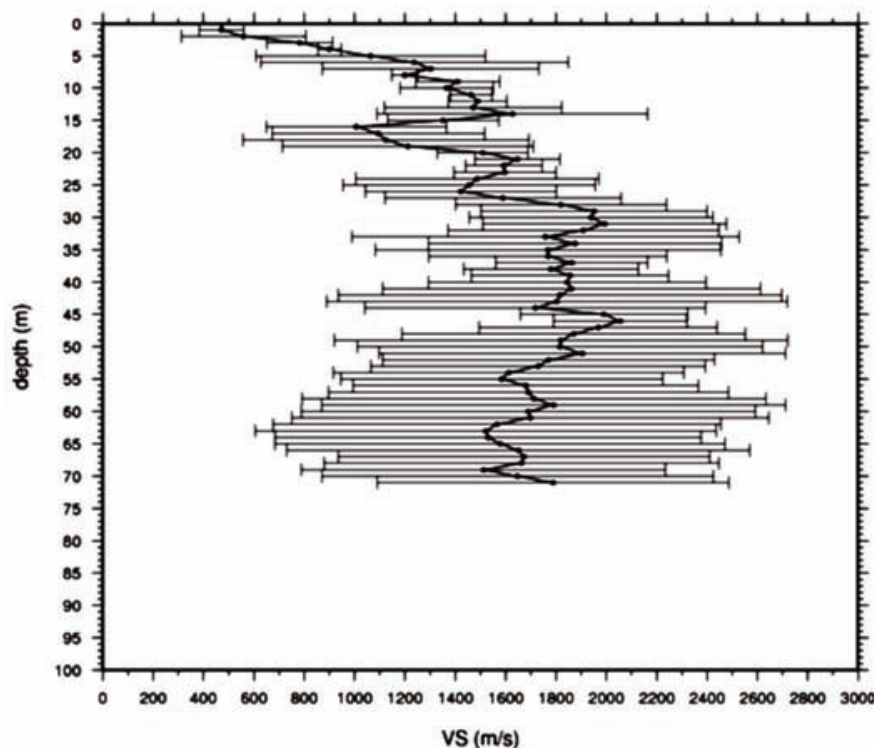

c)

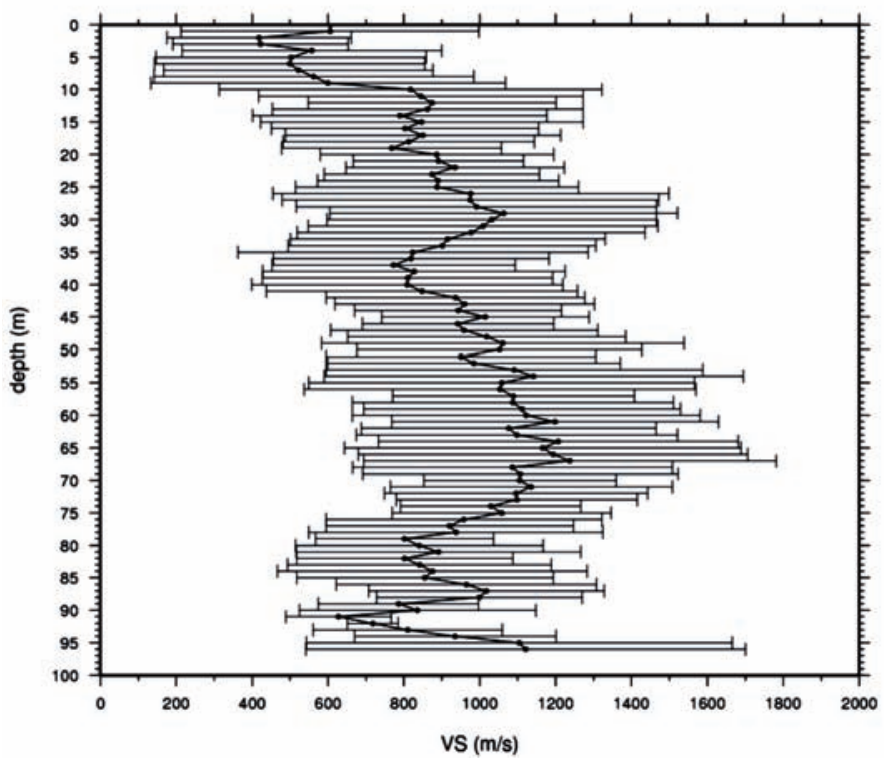

b) QUATERNARY
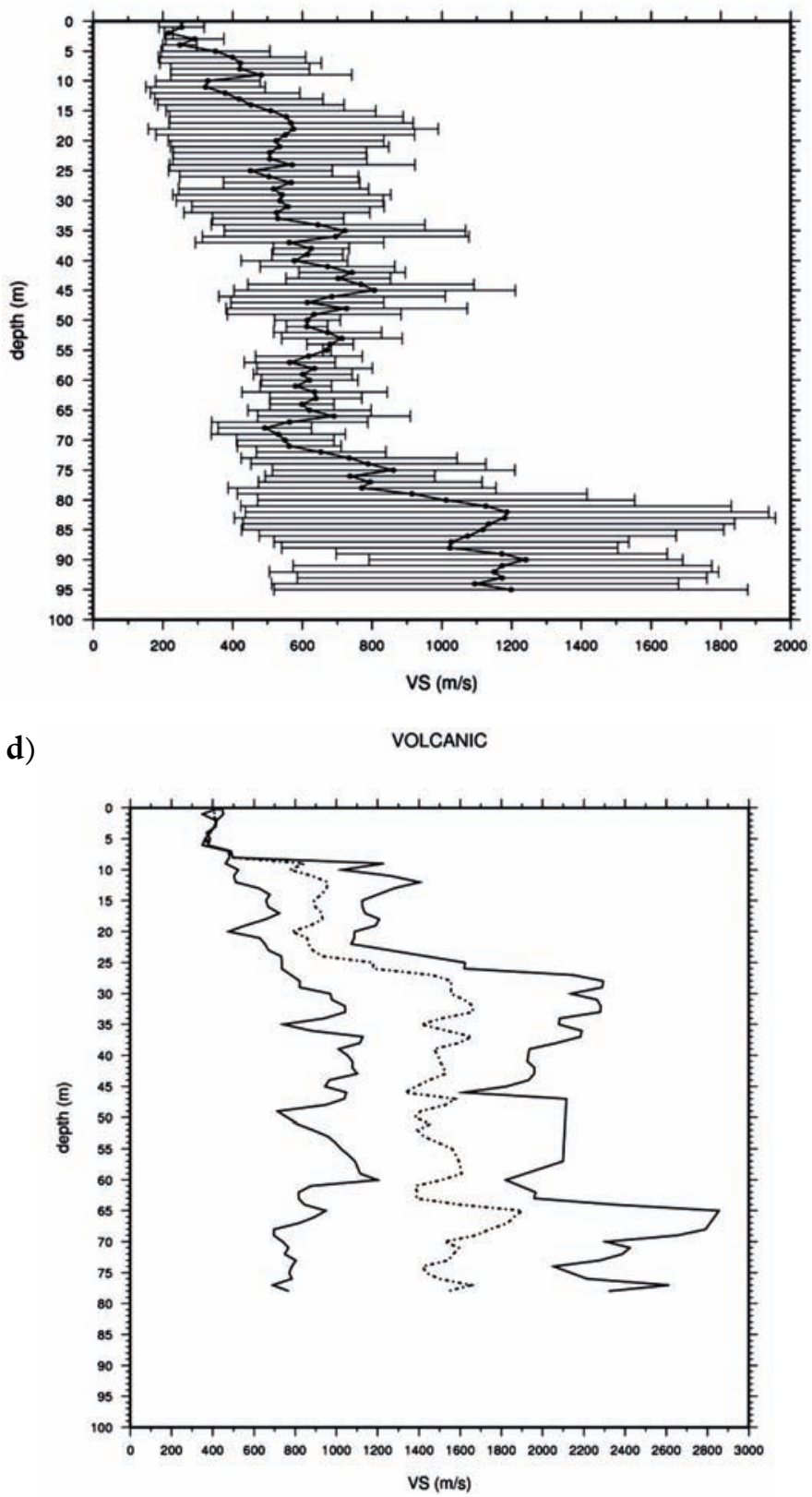

Figure 5. Composite profile for geologic Mesozoic (a), Quaternary (b), Tertiary (c) and Quaternary (d) categories, as mean and standard deviation of shearwave velocity at each meter of depth. For sites classified as Volcanic class (d) the mean (dotted line), the minimum, and maximum profile are shown.

separate the units of different categories (Figure 3).

\section{Shear-wave velocity of the proposed geological categories}

As discussed above, the Vs30 is an important parameter that is used for classifying sites in recent building codes and to predict their potential to amplify ground shaking. As a consequence, a Vs30 value or a range of values must be assigned to each of the identified QVTM categories. The main complication with this approach is that shear-wave velocities are only measured at a few discrete points, and a method of extrapolation is thus necessary for any point other than those sampled. Sometimes, there are too few measurements in a given geological unit to adequately characterize its response, or two geologically distinct units may have similar velocity distributions and thus show similar responses.

For the region considered in the present study, the only profiles currently available are those retrieved from the database of the National Strong Motion Network (RAN) [Working Group ITACA 2010]. These velocity profiles have different depths. Among all of the available profiles, we decided to use only profiles that can be correlated with the mapped category units.

Therefore, in plotting the locations of the site profiles on the QVTM map, we found twelve measured velocity profiles that fall within our site-conditions map. As shown in Figure 3, three fall within the Quaternary category, three within the Mesozoic category, four within the Tertiary category, and only two profiles within the Volcanic category. For each 
Site ground type

Age

$$
\begin{aligned}
& \text { Site natural period } \\
& (\mathrm{T}=4 \mathrm{~h} / \beta)(\mathrm{sec})
\end{aligned}
$$

Vs30

$(\mathrm{m} / \mathrm{s})$
Subsoil class and

$\operatorname{Vs30}(\mathrm{m} / \mathrm{s})$ in EC8
Carbonate platform

successions

Sediments, soft rock and

flysh deposit

Volcanic rock

Quaternary-Tertiary (V)

Alluvium and

Quaternary (Q)

gravel deposits

Very soft soils
$0.12=\mathrm{T}<0.3$

$0.3=\mathrm{T}<0.6$

Mesozoic (M)

Tertiary (T)

$0.15=\mathrm{T}<0.3$

$\mathrm{T}=0.6$
Ranging from

1122 to 1153

Ranging from

365 to 976

Ranging from

539 to 506

Ranging from

192 to 506
A (rock)

Vs $>800$

B (stiff soil)

$360<$ Vs $<800$

B (stiff soil)

$360<$ Vs $<800$

C (soft soil)

$180<\mathrm{Vs}<360$

D $<180$ (very soft soil)

Table 1. Comparisons between the QVTM categories, the computed natural period, and Vs30 values of the sites, and the EC8 site classes [2003].

profile of soil or rock, the representative average Vs30 has been computed from the travel time of the vertically propagating shear waves, according to the theoretical modelling of a uniform soil layer on top of the bedrock:

$$
\mathrm{Vs} 30=\frac{30}{\sum_{i=1, \mathrm{~N}} \frac{h_{i}}{V_{i}}}
$$

where $h_{i}$ and $V_{i}$ denote the thickness in meters and shear-wave velocity in $\mathrm{m} / \mathrm{s}$, respectively, of the ith formation or layer, in a total of $\mathrm{N}$, in the top $30 \mathrm{~m}$.

In these classification codes the depth of the first resonant layer is connected not only with the frequency, but also with the amplitude of local site responses.

The shear-wave velocity profiles and the calculated Vs30 values for each category are shown in Figure 4. Vs30 values calculated from profiles belonging to the Mesozoic class are quite uniform, ranging from $1122 \mathrm{~m} / \mathrm{s}$ to $1153 \mathrm{~m} / \mathrm{s}$ (Figure 4a). These values are mostly representative of fractured hard rock.

The widespread Tertiary sedimentary successions, instead, are highly variable, both in lithology and amount of deformation. Commonly, these units are subdivided on geological maps into many formations based on age, grain size and lithology. We have found that the various flysch units that outcrop prevalently in the central sector of the southern Apennines show Vs30 ranging from $524 \mathrm{~m} / \mathrm{s}$ to $976 \mathrm{~m} / \mathrm{s}$ depending on the weathering and amount of fracturing (Figure 4b). The only profile available for the younger fine-grained deposits of the Tertiary age (Miocene and Pliocene) in an external area of the Apennine belt shows a Vs30 of $365 \mathrm{~m} / \mathrm{s}$.

Quaternary units typically present extremely variable velocity characteristics because they vary in thickness, grain size, density, porosity, and cementation. In the present study, we found that these young soil deposits have Vs30 values ranging from about $192 \mathrm{~m} / \mathrm{s}$ to $506 \mathrm{~m} / \mathrm{s}$ (Figure 4c). The few Vs profiles currently available suggest that the Vs30 calculated for these units are only crude approximations of the Vs characteristics of the Quaternary units. Furthermore, Vs measurements would allow the identification of variations in thickness and grain size, and an attempt to subdivide those units into several classes should be made.

Only two Vs profiles are available for TertiaryQuaternary volcanic units. One of these two was measured in pyroclastic flows of Mt. Vesuvio, with the other one in sodic potassic lahars of Mt. Vulture. The average $618 \mathrm{~m} / \mathrm{s}$ Vs30 value of these profiles is typical of volcanic rock, which is harder than younger Tertiary deposits (Figure $4 \mathrm{~d}$ ). Generally, because of their lithological variability, the volcanic rocks have variable velocity characteristics. Units such as basalt (hard rock, but extensively fractured), and pyroclastic rock (loose agglomerations of volcanic ash) tend to have velocities ranging from about $360 \mathrm{~m} / \mathrm{s}$ to about 1000 $\mathrm{m} / \mathrm{s}$ depending on the weathering and amount of shearing.

For each geological category, we also computed a composite shear-wave profile following the method proposed by Wills et al. [2000]. These profiles were obtained by calculating the means and standard deviations of shearwave velocities using a 1 -m-depth sampling. Composite profiles help to highlight possible deficiencies in the available dataset and units that must be further subdivided.

Figure 5 shows the composite profile for each geologic class, along with the standard error. Although we have few profiles for each category, all of the composite profiles clearly show variability of shear-wave velocity with depth and large 
vertical variation of standard error. Moreover, as reported in Wills at al. [2000], the shape and the variability of Vs profiles can also allow the identification of where vertical variations along the Vs profile affect the Vs30 characteristics of a unit, where materials with differing Vs have been included in the same unit, or whether a unit is extremely variable. The composite profile for the Mesozoic class shows a relatively rapid increase in velocity from about $500 \mathrm{~m} / \mathrm{s}$ at the surface to over $1600 \mathrm{~m} / \mathrm{s}$ at $15 \mathrm{~m}$ (Figure $5 \mathrm{a}$ ). Then, after three velocity inversions, it shows a high variability until a $72-\mathrm{m}$ depth. The large standard deviations throughout the composite profile reflect the variable shear-wave velocities related to the different degrees of deformation that the rock has undergone.

The composite profile for the Tertiary class shows a slow increase in velocity, from about $600 \mathrm{~m} / \mathrm{s}$ at the surface to over $1000 \mathrm{~m} / \mathrm{s}$ at $95 \mathrm{~m}$ in depth (Figure $5 \mathrm{~b}$ ). The apparent regularity in the profile is probably due to the little data measured on sites that are near, so located in the central sector of Apenninic chain. So, this composite profile is representative only of the Tertiary units that outcrop in the central sector of the southern Apennines.

The composite profile for the Quaternary class shows an almost steady increase in velocity to $70 \mathrm{~m}$, and a more gradual increase both in velocity and in standard deviation from $70 \mathrm{~m}$ to $95 \mathrm{~m}$ (Figure $5 \mathrm{c}$ ). The velocity values are higher than would be measured at a site on alluvium deposits. Generally, alluvium deposits have Vs30 ranging from 180 $\mathrm{m} / \mathrm{s}$ to $360 \mathrm{~m} / \mathrm{s}$, as reported for EC8 Site Classes [2003]. It is likely that the measurements were carried out in basins where young and thin deposits are at the surface, while the harder materials are at a shallow depth in the subsurface. In these situations, Vs profiles can include significant thicknesses of harder rock that lies underneath a thin layer of alluvium deposits. Given the small number of profiles measured in these units, we did not subdivide the young deposits based on thickness and grain size.

For the Volcanic category we calculated only the mean value, because to date only two shear-wave velocity profiles are available. The composite profile features rapid increases in velocity from about $400 \mathrm{~m} / \mathrm{s}$ at the surface to over 1600 $\mathrm{m} / \mathrm{s}$ at $80 \mathrm{~m}$ (Figure $5 \mathrm{~d}$ ). Clearly for these units, as with the Quaternary units, it would be desirable to have more shearwave velocity measurements and more geological data in order to highlight significant variations in site responses for mapped young sediments.

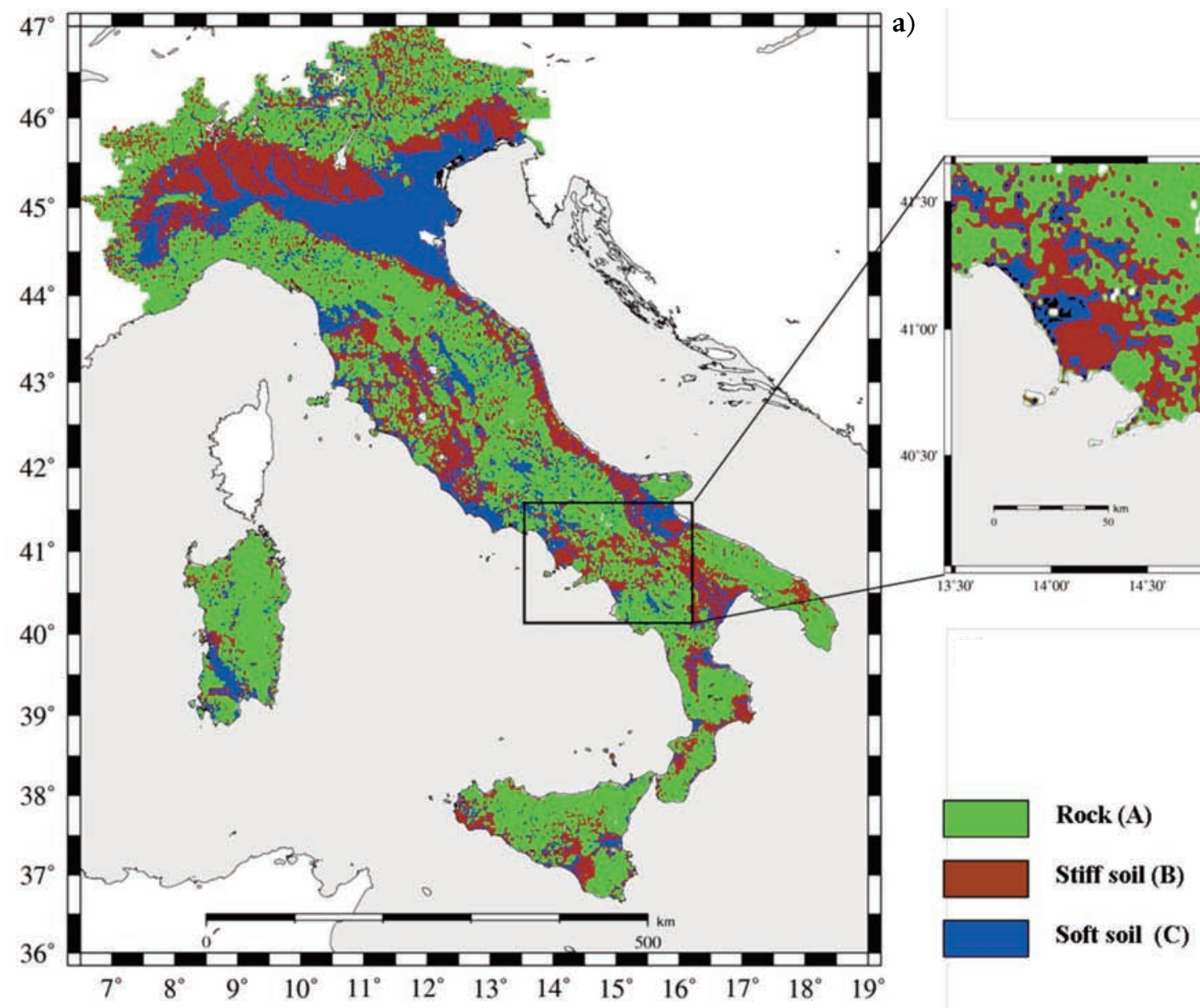

Figure 6. a). Geological-Class Map at 1:500,000 scale [Servizio Geologico d'Italia, 1978], reclassified according to the EC8 [Luzi and Meroni 2007]. b). Zoom in on the region of interest. 


\section{Site classification using average shear-wave velocity}

To test the accuracy of our geologically defined site categories, we classified each site category in terms of the EC8 site classes, comparing the lithological features and the Vs30 values inferred from our analysis with the EC8 categories.

EC8 identifies seven ground types, A, B, C, D, E, S1 and $S 2$, that are described by the stratigraphic profiles, and that can be used to account for the influence of local ground conditions on seismic actions. Starting from class A, corresponding to hard rock or hard rock covered by very thin soil deposits, the EC8 code details ground with gradually decreasing rigidity until ground types $\mathrm{S} 1$ and $\mathrm{S} 2$, which are much more deformable. Following the provisions of EC8, sites can be classified according to the Vs30 parameter, if it is available, and otherwise by the NSPT (Standard Penetration Test) value. Recent developments in soil classification also include the predominant period of a site as a site-class parameter [Japan Road Association 1980, 1990]. To a first order approximation, the dominant period is estimated as four times the $S$-wave travel time in the soil layer, assuming that the medium can be represented by a single soil layer 30 $\mathrm{m}$ in width, with a constant shear-wave velocity.

Table 1 lists the outcropping formations of the Campania-Lucania region grouped into the four site classes of QVTM that follow the lithological and age criteria, the associated Vs30 values, the calculated dominant site period, and the categories from EC8. Our database is predominantly composed of ground types A, B and C, and we have not found any sites belonging to class D. However, all of the measured Vs30 values fall within the expected ranges for the units within which they are located.

The QVTM map (Figure 3) was compared with the Geological-Class Map produced by Cultrera et al. [2003] in the GNDT-INGV Project (framework program 2000-2002). This map was built to introduce the role of local geology into the seismic-hazard evaluation at the national scale. In this context, the geological units of the 1:500,000 Italian geological map [Servizio Geologico d'Italia, 1978] were grouped into three classes, A, B, C, according to the EC8 using lithological and age criteria (Figure 6). Due to the large scale of the original geological map, the small-size Quaternary basins characterizing the Apennines were often missed. The comparison between the two maps shows the better detail of the QVTM map. In the national GeologicalClass Map shown in Figure 6, the volcanic units that are extensively diffuse in the Campania-Lucania region have not been characterized. In practice, it is better to consider these volcanic units as an additional class, due to their attenuation characteristics that can greatly affect the ground-motion values. Additionally, the QVTM map shows better characterization of the units that outcrop along the central sector of the southern Apennines.

\section{Conclusions}

To account for site conditions in calculating seismic hazards or ground-shaking maps soon after a moderate-tolarge earthquake, a possible way that has been investigated in several studies is to build a site classification using the average wave velocity to $30 \mathrm{~m}$ as an indicator of the quality of sites [e.g, Wald and Mori 2000, Wills et al. 2000, Wills and Clahan 2006].

Using the available information of the local geology, we have developed some generalized site classes according to the European norm, commonly referred to as EC8. The approach and geological categories described in this study have resulted in a map, the QVTM site-conditions map, that yields site-conditions information for some of the units of the Campania-Lucania region. As underlined in Wills et al. [2000], the accuracy of a site-conditions map is limited by the number of Vs profiles available. It is clear that it is necessary to have a significant amount of data to represent each unit as a whole. Due to the lack of sufficient Vs profiles, we have not been able to highlight those areas with different thicknesses of younger deposits, nor to separate areas where coarser grain size might lead to higher velocities, or others where finer alluvium might lead to lower velocities. Consequently, our approach has been to consider only the general geological categories, alluvium, soft rock and hard rock, that are correlated with the site-conditions terms used in strong ground-motion attenuation equations.

To further refine this proposed map, detailed information on Quaternary and Volcanic units are needed to underline significant variations in site responses for mapped young sediments. However, the resulting site classification map can provide a basis as is or in conjunction with other factors, for more precise characterisation of site conditions in probabilistic seismic-hazard calculations.

Acknowledgements. The authors wish to thank AMRA scarl (www.amra.unina.it) for the financial support of this study in the framework of the SAFER project (Sixth Framework Programme for Sustainable Development, Global Change and Ecosystem Priority 6.3.IV.2.1: reduction of seismic risks contract for specific targeted research or innovation project, contract no. 036935), and in the collaboration with the Italian Dipartimento della Protezione Civile in the framework of the SAMS project. We would specifically like to thank Giovanna Cultrera for the revisions made to the manuscript and for his constructive comments. The Figures were prepared using the GMT software [Wessel and Smith 1991].

\section{References}

Abrahamson, N.A., and W.J. Silva (1997). Empirical response spectral attenuation relations for shallow crustal earthquakes, Seismol. Res. Lett., 68 (1), 94-127.

Akkar, S., and J.J. Bommer (2007). Empirical Prediction Equations for Peak Ground Velocity Derived from Strong-Motion Records from Europe and the Middle East, B. Seismol. Soc. Am., 97 (2), 511-530; doi: 10.1785/0120060141.

Anderson, H.J., and J. Jackson (1987). Active tectonics of the Adriatic Region, Geophys. J. Roy. Astr. S., 91 (3), 937-983. 
Bard, P.-Y., and M. Bouchon (1985). The two-dimensional resonance of sediment-filled valleys, B. Seismol. Soc. Am., 75 (2), 519-541.

Bard, P.-Y., M. Campillo, F.J. Chavez-Garcia and F.J. SanchezSesma (1988). A theoretical investigation of large- and small-scale amplification effect in the Mexico City valley, Earthquake Spectra, 4 (3), 609-633.

Bernard, P., and A. Zollo (1989). The Irpinia (Italy) 1980 earthquake: Detailed analysis of a complex normal fault, J. Geophys. Res., 94 (B2), 1631-1647.

Bonardi, G., B. D'Argenio and V. Perrone (1992). Carta geologica dell'Appennino meridionale (1:250 000), Atti del $74^{\circ}$ Congresso della Società Geologica Italiana: L'Appennino Campano-Lucano nel quadro geologico dell'Italia Meridionale (Sorrento, 13-17 Settembre 1988), Roma.

Boore, D.M., W.B. Joyner and T.E. Fumal (1993). Estimation of response spectra and peak accelerations from western North American earthquakes: An interim report, U.S. Geological Survey Open-File Report 93-509, 72 pp.

Boore, D.M., W.B. Joyner and T.E. Fumal (1994). Estimation of response spectra and peak accelerations from western North American earthquakes: An interim report, Part 2, U.S. Geological Survey Open-File Report 94-127, 40 pp.

Boore, D.M., W.B. Joyner and T.E. Fumal (1997). Equations for estimating horizontal response spectra and peak acceleration from western North American earthquakes: A summary of recent work, Seism. Res. Lett., 68 (1), 128-153.

Boore, D.M., and G.M. Atkinson (2008). Ground-Motio Prediction Equations for the Average Horizontal Component of PGA, PGV, and 5\%-Damped PSA at Spectral Periods between $0.01 \mathrm{~s}$ and $10.0 \mathrm{~s}$, Earthquake Spectra, 24 (1), 99-138.

Borcherdt, R., C.M. Wentworth, A. Janssen, T. Fumal and J. Gibbs (1991). Methodology for predictive GIS mapping of special study zones for strong ground shaking in the San Francisco Bay region, CA, In: Proceedings of the Fourth International Conference on Seismic Zonation, Earthquake, August 25-29, 1991, Stanford, California, Earthquake Engineering Research Institute, vol. III, 545-552.

Borcherdt, R.D. (1994). Estimates of Site-Dependent Response Spectra for Design (Methodology and Justification), Earthquake Spectra, 10 (4), 617-653.

Boschi, E., E. Guidoboni, G. Ferrari, G. Valensise and P. Gasperini (1997). Catalogo dei forti terremoti in Italia dal 461 a.C. al 1990, vol. 2, ING-SGA Bologna, 644 pp. (with database on CD-ROM).

Cantore, L. (2008). Determination of site amplification in the Campania-Lucania region (southern Italy) by comparison of different site-response estimation techniques, Ph.D. thesis, Università Federico II di Napoli; http: / / www.fedoa. unina.it/3407/.

Cinque, A., E. Patacca, P. Scandone and M. Tozzi (1993). Quaternary kinematic evolution of the Southern Appennines. Relationships between surface geological features and deep lithospheric structures, Annali di Geofisica, 36 (2), 249-260. Cinti, F.R., L. Faenza, W. Marzocchi and P. Montone (2004). Probability map of the next $M \geq 5.5$ earthquakes in Italy, Geochemistry Geophysics Geosystem, 5 (11), Q 11003; doi: 10.1029/2004GC000724.

Convertito, V., R. De Matteis, L. Cantore, A. Zollo, G. Iannaccone and M. Caccavale (2010). Rapid estimation of ground-shaking maps for seismic emergency management in the Campania Region of southern Italy, Natural Hazard, 52 (1), 97-115; doi: 10.1007/s11069-009-9359-2.

CPTI Working Group (1999). Catalogo Parametrico dei Terremoti Italiani, versione 1 (CPTI99, luglio 1999), INGGNDT-SGA-SSN, Bologna, 88 pp.; http: / / emidius.mi.ingv. it/CPTI99/.

Cultrera, G., A. Rovelli, P. Bordoni, V. De Rubeis, F. Doumaz, L. Luzi, L. Margheriti, F. Marra, M. Moro, D. Sorrentino and P. Tosi (2003). Task 3.2: Local Geology Effect on Seismic Hazard, Progetto GNDT-INGV: Terremoti probabili in Italia tra l'anno 2000 e il 2030: elementi per la definizione di priorità degli interventi di riduzione del rischio sismico (Programma quadro 2000-2002), Relazione Annuale, 39 pp. (available on Earth-prints.org: http: / / www.earthprints.org/handle/2122/5897).

Doglioni, C., P. Harabaglia, G. Martinelli, F. Mongelli and G. Zito (1996). A geodynamic model of the Southern Apennines accretionary prism., Terra Nova, 8 (6), 540-547.

Emolo, A., V. Convertito and L. Cantore (2011). Ground-mo tion predictive equations for low-magnitude earthquakes in the Campania-Lucania area, Southern Italy, J. Geophys. Eng., 8 (1), 46-60; doi: 10.1088/1742-2132/8/1/ 007.

Eurocode 8 (2003). Design of Structures for Earthquake Resistance, Part I: General Rules, Seismic Actions and Rules for Buildings, European Committee for Standardization/ Comité Européen de Normalisation, Doc CEN/TC250/ SC8/N335, Draft No. 6.

Frisenda, M., M. Massa, D. Spallarossa, G. Ferretti and C. Eva (2005). Attenuation relationship for low magnitude earthquakes using standard seismometric records, J. Earthquake Eng., 9 (1), 23-40.

Holzer, T.L., A.C. Padovani, M.J. Bennett, T.E. Noce and J.C. Tinsley III (2005). Mapping Vs30 Site Classes, Earthquake Spectra, 21 (2), 353-370.

Japan Road Association (1980). Specifications for Highway Bridges Part V, Seismic Design, Maruzen Co., LTD.

Japan Road Association (1990). Specifications for Highway Bridges Part V, Seismic Design, Maruzen Co., LTD.

Joyner, W.B., R.E. Warrik and T.E. Fumal (1981). The effect of Quaternary alluvium on strong ground motion in the Coyote Lake, California, earthquake of 1979, B. Seismol. Soc. Am., 71 (4), 1333-1349.

Joyner, W.B., and T.E. Fumal (1985). Predictive mapping of earthquake ground motion, In: Evaluating Earthquake Hazards in the Los Angeles Region-An Earth Science 
Perspective, edited by J.E. Ziony, U.S. Geol. Surv. Profess. Paper 1360, 203-220.

Luzi, L., and F. Meroni (2007). Task 1 - Completamento delle elaborazioni relative a MPS04. Deliverable D6: Valutazioni sperimentali di amax e di spettri di risposta calibrate per le condizioni locali, Convenzione INGV-DPC 20042006/Progetto S1, Milano, 4 aprile 2007, 27 pp.; http:/ / esse1.mi.ingvit/data/D6.pdf.

Massa, M., S. Marzorati, E. D'Alema, D. Di Giacomo and P. Augliera (2007). Site Classification Assessment for Estimating Empirical Attenuation Relationships for Central-Northern Italy Earthquakes, J. Earthq. Eng., 11 (6), 943-967.

NEHRP (1997). NEHRP Recommended Provisions for Seismic Regulations for New Buildings and Other Structures (FEMA 302, 303), 1997 Edition, Prepared by the Building Seismic Safety Council (National Institute of Building Sciences) for the Federal Emergency Management Agency, Washington, D.C.

NEHRP (2004). NEHRP Recommended Provisions for Seismic Regulations for New Buildings and Other Structures (FEMA 450), 2003 Edition, Prepared by the Building Seismic Safety Council (National Institute of Building Sciences) for the Federal Emergency Management Agency, Washington, D.C.

Park, S., and S. Elrick (1998). Prediction of shear wave velocities in Southern California using surface geology, B. Seismol. Soc. Am., 88 (3), 677-685.

Patacca, E., and P. Scandone (1989). Post-Tortonian mountain building in the Apennines. The role of the passive sinking of a relic lithospheric slab, In: A. Boriani, M. Bonafede, G.B. Piccardo, and G.B. Vai (eds.), The lithosphere in Italy: advances in Earth science research, Atti Accad. Naz. Lin., 80, 157-176.

Patacca, E., R. Sartori and P. Scandone (1990). Tyrrhenian Basin and Apenninic Arc: kinematic relations since Late Tortonian times, Memorie della Società Geologica Italiana, 45, 425-451.

Pescatore, T., P. Renda, M. Schiattarella and M. Tramutoli (1999). Stratigraphic and structural relationships between Meso-Cenozoic Lagonegro basin and coeval carbonate platforms in southern Apennines, Italy, Tectonophysics, 315 (1-4), 269-286.

Roure, F., P. Casero and R. Vially (1991). Growth processes and melange formation in the Southern Apennines accretionary wedge, Earth Planet. Sc. Lett., 102 (3-4), 395-412.

Servizio Geologico d'Italia (1978). Carta geologica d'Italia nella scala 1:500.000, Fogli 1-5 (1976-1984), Foglio relativo all'area d'interesse, Istituto Poligrafico e Zecca dello Stato.

Wald, D.J., V. Quitoriano, T.H. Heaton, H. Kanamori, C.W. Scrivner and C.B. Worden (1999). TriNet "ShakeMaps": Rapid Generation of Peak Ground Motion and Intensity Maps for Earthquakes in Southern California, Earthquake Spectra, 15 (3), 537-556.
Wald, L.A., and J. Mori (2000). Evaluation of Methods for Estimating Linear Site-Response Amplifications in the Los Angeles Region, B. Seismol. Soc. Am., 90 (6B), S32-S42.

Weber, E., V. Convertito, G. Iannaccone, A. Zollo, A. Bobbio, L. Cantore, M. Corciulo, M. Di Crosta, L. Elia, C. Martino, A. Romeo and C. Satriano (2007). An Advanced Seismic Network in the Southern Apennines (Italy) for Seismicity Investigations and Experimentation with Earthquake Early Warning, Seismol. Res. Lett., 78 (6), 622-634.

Wessel, P., and W.H.F. Smith (1991). Free software helps map and display data, Eos. Trans. AGU, 72 (41), 441.

Westaway, R., and J. Jackson (1987). The earthquake of 1980 November 23 in Campania-Basilicata (southern Italy), Geophys. J. Roy. Astr. S., 90 (2), 375-443.

Westaway, R. (1992). Seismic Moment Summation for Historical Earthquakes in Italy: Tectonic Implications, J. Geophys. Res., 97 (B11), 15437-15464.

Wills, C.J., M. Petersen, W.A. Bryant, M. Reichle, G.J. Saucedo, S. Tan, G. Taylor and J. Treiman (2000). A Site-Conditions Map for California Based on Geology and Shear-Wave Velocity, B. Seismol. Soc. Am., 90 (6B), S187-S208.

Wills, C.J., and K.B. Clahan (2006). Developing a Map of Geologically Defined Site-Condition Categories for California, B. Seismol. Soc. Am., 96 (4A), 1483-1501.

Working Group ITACA (2010). Data Base of the Italian strong motion records; http:/ /itaca.mi.ingv.it.

\footnotetext{
${ }^{\star}$ Corresponding author: Luciana Cantore, Università degli Studi di Napoli «Federico II», Dipartimento di Scienze Fisiche, Napoli, Italy; e-mail: lucycant.cantore@googlemail.com.

(C) 2010 by the Istituto Nazionale di Geofisica e Vulcanologia. All rights reserved.
} 